\title{
PEREMPUAN BIMA DAN STRATEGI ADAPTASI PASCA BENCANA BANJIR BANDANG (STUDI KASUS PERAN PEREMPUAN DI KABUPATEN BIMA, NTB)
}

\author{
Ika Wijayanti, Oryza Pneumatica I, Siti Nurjannah \\ Prodi Sosiologi Universitas Mataram \\ wijayaika0505@gmail.com
}

\begin{abstract}
The research titled "Bima's Women and Post Disaster Mitigation Adaption Strategy for flash floods (Case Study of Women in Maintaining family Economics After The Flash Floods Disaster in Bima)" Takes place in Nisa Village, Woha Subdistrict, Bima District. By doing this research, the researcher are expected to be able to: (1) knowing in depth the adaptive strategy done by women in reconstructing their social life after flash floods disaster, (2) knowing the change of life after flash floods, (3) knowing the obstacles faced by women in the implementation post flash floods adaptive strategy.

This research uses explorative qualitative research method. The research location is located in Nisa Village, Woha District, Bima District, West Nusa Tenggara Province. The subjects of this study were women housewives and Nisa village apparatus. Data were collected through interviews and observations to collect information on adavtive strategies, changes in postflash floods life, and the constraints faced by women in implementing adaptive strategies after the flash floods disaster. Further data analysis by performing several stages that include data collection, data classification, interpretation to the writing of research reports.

The results of this research show that (i) Nisa village women experiencing changes in economic, social and cultural life after the disaster flash floods. (ii) adaptive strategies implemented by Nisa village women in sustaining their household economies, among others, by active strategies in the form of exploiting natural resources and human resources from close relatives, extending working hours, and working to reduce family economic expenditure. The network strategy undertaken by Nisa village women is by owing the banks and neighbors. (iii) the constraints faced by women in Nisa village in carrying out an effective strategy are the loss of some natural resources that can support economic recovery, large losses due to flood disaster become an obstacle in economic recovery, and lack of acces to village economic institutions.
\end{abstract}

Keywords: women, adaptive strategy, flash floods disaster 


\section{Abstrak}

Penelitian dengan judul "Perempuan Bima dalam Strategi Adaptasi Pasca Bencana Banjir Bandang (Studi Kasus Perempuan Dalam Mempertahankan Ekonomi Keluarga Pasca Bencana Banjir Bandang di Kabupaten Bima)" ini mengambil Lokasi di Desa Nisa, Kecamatan Woha Kabupaten Bima. Dengan dilakukannya penelitian ini diharapkan Peneliti mampu: (1) mengetahui secara mendalam strategi adaptif yang dilakukan perempuan dalam merekonstruksi kehidupan sosial ekonominya pasca bencana banjir bandang, (2) mengetahui perubahan kehidupan pasca bencana banjir bandang, (3) mengetahui kendala yang dihadapi perempuan dalam pelaksanaan strategi adaptif pasca bencana banjir bandang.

Penelitian ini menggunakan metode penelitian kualitatif eksploratif. Lokasi penelitian berada di Desa Nisa, Kecamatan Woha Kabupaten Bima, Provinsi Nusa Tenggara Barat. Subyek dari penelitian ini adalah perempuan ibu rumah tangga dan perangkat Desa Nisa. Data dikumpulkan melalui wawancara dan observasi untuk menghimpun informasi mengenai strategi adaptif, perubahan kehidupan pascabencana banjir bandang, dan kendala-kendala ayng dihadapi oleh perempuan dalam menjalankan strategi adaptif pasca bencana banjir bandang. Selanjutnya data dianalisis dengan melakukan beberapa tahapan yang meliputi pengumpulan data, klasifikasi data, interpretasi hingga penulisan laporan penelitian.

Hasil penelitian ini menunjukan bahwa (i) perempuan Desa Nisa mengalamai perubahan kehidupan baik ekonomi, sosial, dan budaya pasca bencana banjir bandang. (ii) strategiadaptifyang dilakukan oleh perempuan Desa Nisa dalam mempertahankan ekonomi rumah tangganya antara lain dengan strategi aktif yang berupa pemanfaatan sumber daya alam dan sumber daya manusia dari keluarga terdekat, memperpanjang jam kerja, serta mengusahakan lapangan pekerjaan baru. Strategi pasif yang dilakukan oleh perempuan Desa Nisa dengan cara mengurangi pengeluaran ekonomi keluarga. Strategi jaringan yang dilakukan oleh perempuan Desa Nisa adalah dengan mengutang pada bank dan tetangga. (iii) kendala yang dihadapi perempuan Desa Nisa dalam melakukan strategi adaptif adalah hilangnya sebagian sumber daya alam yang dapat menunjang perbaikan ekonomi, kerugian yang banyak akibat bencana banjir menjadi kencala dalam pemulihan ekonomi, dan kurangnya akses ke lembaga ekonomi desa.

Kata Kunci: perempuan, strategi adaptif, dan bencana banjir bandang

\section{PENDAHULUAN}

Provinsi Nusa Tenggara Barat (NTB) dengan luas wilayah 20.153,15 km2, terdiri dari dua pulau yaitu Pulau Lombok dan Pulau Sumbawa. Terletak antara $115^{\circ} 46^{\prime}-119^{\circ} 5^{\prime}$ Bujur Timur dan $8^{\circ} 10^{\prime}$ - $9{ }^{\circ} \mathrm{g} 5^{\prime}$ Lintang Selatan, provinsi NTB memiliki kontur wilayah yang beragam dari pegunungan, pantai, hingga padang savana. Di Pulau Lombok terdapat Gunung Rinjani merupakan gunung tertinggi dengan ketinggian $3.775 \mathrm{~m}$, sedangkan Gunung Tambora merupakan gunung tertinggi di Sumbawa dengan ketinggian $2.851 \mathrm{~m}$ (diolah dari provntb.go.id).

Berdasarkan letak geografisnya, Nusa Tenggara Barat memiliki iklim yang kering dengan periode hujan yang singkat. Namun, seiring dengan perubahan iklim dunia, mengakibatkan NTB juga terkena dampaknya. Pada tahun 2010, sebenarnya NTB telah menjadi perhatian dari Kementrian Lingkungan akibat seringnya terjadi anomali cuaca. Pulau Lombok, yang dikelilingi lautan, sangat mudah terpengaruh oleh kenaikan tinggi air laut, 
terutama terhadap bahaya banjir atau rob, sedimentasi, dan erosi. Kondisi seperti ini semakin rentan akibat meningkatkan frekuensi iklim ekstrem, seperti El Nino dan La Nina (wwf, 2010). Anomali iklim di NTB hingga sekarang ini masih terjadi mengakibatkan curah hujan yang tidak menentu. Kondisi ini membawa dampak bagi lingkungan dan masyarakat.

Salah satu dampak yang sangat terasa bagi masyarakat adalah terjadinya banjir bandang yang berulang pada ahir tahun 2016 dan awal tahun 2017 di Kabupaten Bima. Banjir merendam 33 desa di 5 kecamatan di Kota Bima dan Kabupaten Bima yang meliputi Kecamatan Rasanae Timur, Mpunda, Raba, Rasanae Barat, Woha, Wawo, dan Asakota. Diperkirakan, penyebab dari terjadinya banjir di Bima adalah Siklon Tropis Yvette yang menimbulkan curah hujan ekstrem pada kawasan Nusa Tenggara dan sekitarnya. Faktor lain yang ditengarai sebagai penyebab banjir bandang adalah kerusakan lingkungan karena alih fungsi lahan yang terkonversi menjadi lahan pertanian dan perkebunan. Selain itu, sedimentasi sungai juga turut andil dalam memperparah banjir bandang. Pemerintah Kota Bima memperkirakan kerugian dari harta penduduk mencapai Rp 607,93 miliar, total kerugian ditaksir mencapai 1 triliun (diolah dari koran Tempo, 2016).

Intensitas bencana yang semakin meningkat karena ketidakpedulian pada fenomenaalam dankerusakanlingkungan baik dari kebijakan pemerintahnya dan apatisme masyarakat, memaksa masyarakat harus merekonstruksi kehidupan hidupnya kembali. Hal ini tentu saja membutuhkan strategi adaptif pasca bencana banjir. Apalagi bencana banjir ini berulang dan anomali cuaca masih berlangsung.
Strategi adaptif masyarakat pasca bencana merupakan strategi yang krusial di tengah keterbatasan sumber daya yang ikut porak poranda. Kualitas kehidupan sosial ekonomi yang mengalamani penurunan akan membuat masyarakat mencari strategi terbaik demi menjaga kelangsungan hidupnya. Respon strategi adaptif masing-masing individu tidak dapat dipersepsikan sama, banyak faktor yang melingkupi bagaimana individu atau kelompok menggunakan beradaptasi dengan kondisi pasca bencana. Sebagai bagian dari masyarakat, individu tidak bisa terlepas bagaimana kelompok atau komunitas digunakan sebagai bagian dari strategi adaptif.

Perempuan, sebagai bagian dari sumber daya manusia memerankan peranan penting dalam pengelolaan lingkungan. Termasuk perempuan dalam rumah tangga di Nusa Tenggara Barat banyak bekerja sebagai penyokong ekonomi keluarga. Kaum perempuan dituntut untuk menyesuaikan diri dengan perubahan yang ada dalam keluarga sehingga butuh strategi demi mempertahankan kondisi ekonomi keluarga. Keberlangsungan kehidupan keluarga ditambah dengan beban pekerjaandomestikmendesakperempuan mencari alternatif penghasilan tambahan dengan jalan cerdik.

Strategi adaptif berlaku pada lingkungan-lingkungan manusia yang memiliki tingkatan yang begitu tinggi, baik pada pergolakan lingkungan tempat tinggal dan juga perubahan yang terjadi dalam lingkungan dimana manusia tinggal. Dalam pasca bencana, manusia sebagai individu yang independent atau sebagai bagian dari masyarakat harus melakukan sebuah rekonstruksi atau membangunulang kehidupan ekonominya 
untuk meraih kesejahteraannya kembali. Konsekuensi yang dari adanya bencana membuat masyarakat mencari bentuk adaptasi baru dengan mata pencaharian yang ada atau dengan mencari sumbersumber mata pencarian baru untuk memenui kebutuhan hidupnya.

Bila sebelumnya masyarakat Kabupaten Bima sepenuhnya bergantung kepada alam yang selalu tersedia baik dari wilayah sendiri atau didatangkan dari daerahlain, maka perubahanterjadimereka harus mempersiapkan diri setiap saat menghadapi kondisi alam yang berubah dengan adanya banjir. Terkait dengan bencana banjir bandang yang menimpa masyarakat kabupaten Bima, perempuan sebagai penggerak ekonomi keluarga juga harus siap dengan konsekuensi yang dihadapi. Strategi-strategi yang dilakukan perempuan pekerja tentunya juga tidak sama berdasarkan kondisi latar belakang si perempuan itu sendiri dan keluarganya.

\section{RUMUSAN MASALAH}

Permasalahan yang dirumuskan pada penelitian ini yaitu sebagai berikut:

1. Bagaimana strategi adaptif yang dilakukan perempuan dalam merekonstruksi kehidupan sosial ekonominya pasca bencana banjir bandang?

2. Bagaimana perubahan kehidupan pasca bencana banjir bandang?

3. Apa kendala yang dihadapi perempuan dalam pelaksanaan strategi adaptif pasca bencana banjir bandang?

\section{METODE PENELITIAN}

Penelitian ini menggunakan metode penelitian kualitatif eksploratif. Pada tahap awal peneliti mengumpulkan informasi seputar deskripsi umum mengenai perubahan yang terjadi pasca bencana banjir. Berlanjut kemudian penggalian informasi lebih mendalam mengenai strategi adaptif yang dilakukan oleh perempuan dalam mempertahankan ekonomi keluarga.

Lokasi penelitian ini berada di Desa Nisa, Kecamatan Woha, Kabupaten Bima. Relevansi pemilihan lokasi penelitian ini dengan tujuan penelitian yakni guna mendapatkan gambaran yang lebih rinci mengenai strategi adaptif yang dilakukan oleh perempuan pasca bencana bajir bandang. Selain itu, ditinjau secara administratif kondisi lokasi penelitian yang berada di Kabupaten Bima merupakan desa yang diterjang bencana banjir paling parah.

Informan sebagai sumber informasi adalah pelaku atau perempuan yang melakukan strategi adaptif pasca bencana banjir. Untuk mempermudah mencapai tujuan penelitian, maka teknik penentuan informan dilakukan dengan purposive sampling dengan teknik snowball untuk memperkaya data.

Data atau informasi penelitian akan dihimpun melalui teknik wawancara mendalam dengan menggunakan instrumen penelitian yang mengacu pada tujuan penelitian dan kebutuhan data penelitian. Selain itu, untuk melengkapi informasi yang didapat tersebut juga dilakukan observasi tidak langsung dengan mengamati kondisi empirik informan saat proses wawancara berlangsung. Serta informasi data sekunder dari pelaku ekonomi yang terlibat dalam aktivitas perempuan strategi adaptif pasca bencana banjir.

Analisis data penelitian ini dilakukan menggunakan metode kualitatif. Adapun proses analisis dilakukan dalam beberapa 
tahapan yang meliputi pengumpulan data, klasifikasi data, interpretasi hingga penulisan laporan penelitian.

\section{LANDASAN TEORI}

\section{Adaptasi sebagai Bagian Strategi Hidup Perempuan}

Pada dasarnya manusia menginginkan kehidupan yang lebih baik dengan memenuhi kebutuhan primer, sekunder dan tersier maka dari itu adaptasi dilakukan oleh manusia. Adaptasi merupakan hasil akhir sikap masyarakat yang muncul berdasarkan persepsi dan pengetahuan mereka terhadap banjir pasang surut. Kajian mengenai adaptasi ini dilakukan dengan menilai populasi pada kondisi sosioekologi berbeda. Mileti dan Gottschlich (2001) mengemukakan bahwa kerugian bencana merupakan hasil dari interaksi dari proses fisik alam, karakteristik sosial kependudukan, dan kondisi lingkungan terbangun. Perbedaan karakteristik dari ketiga sistem tersebut menghasilkan kerugian berbeda pada bencana alam yang berbeda. Secara lebih dalam, penelitian mengungkap tentang strategi adaptasi masyarakat dalam menghadapi bencana banjir pasang surut berdasarkan perbedaan karakteristik tersebut.

Adaptasi tidak selalu dihubungkan pada penegasan lingkungan secara normatif, tetapi dalam beberapa hal pada pola dari lingkungan atau hanya kondisi yang extreme. Adaptasi seharusnya dilihat sebagai respon kultural atau proses yang terbukapada proses modifikasi dimana penanggulangan dengan kondisi untuk kehidupan oleh reproduksi selektif danmemperluasnya. Ukuran-ukuran bekerja berdasar pada adapatasi yang dilibatkan, dan lebih penting lagi, pada bahaya/resiko yang mana perubahan adalah adaptif (Hardestry, 243).
Kondisi yang ekstrem ini merupakan kondisi yang diluar dugaan, yang tidak serta merta terjadi sehari-hari sehingga mengakibatkan perubahan dalam kehidupan. Salah satu kondisi ekstrem yang terkait dengan lingkungan adalah bencana alam seperti yang terjadi pada ahir tahun 2016 dan awal tahun 2017 di Bima, yaitu bencana banjir bandang. Keadaan ini memaksa perempuan untuk sensitif terhadap perubahan yang terjadi yang berujung pada munculnya strategi adaptif untuk mempertahankan ekonominya.

Strategi adaptasi setiap individu berbeda dengan individu lainnya. Dalam sosiologi dan antropologi ketika berbicara tentang adaptasi, kita memfokuskan diri kepada kelompok sosial, tidak dengan individual personal. Kelompok ini (institusi/organisasi) tidak secara langsung teramati, mereka merupakan abstraksi dari perilaku individula yang diamati. Lebih spesifik, kita berbicara tentang instusi yang ada dalam masyarakat, tetapi yang kita pelajari adalah individu, dalam konteks ini adalah subjek perempuan itu sendiri.

Menurut Hardestry, bahwa adaptasi merupakan konsep sentral dalam studi ekologi evolusioner karena itu merupakan suatu proses melalui hubungan-hubungan yang menguntungkan antara oganisme dengan lingkungan yang dibangunnya. Dinamika adaptif mengacu pada perilaku yang didesain pada pencapaian tujuan dan kepuasan kebutuhan dan keinginan dan konsekuensi dari perilaku untuk individu, masyarakat, dan lingkungan. Ada 2 mode analitik utama pada perilaku ini: yaitu tindakan individu yang didesain untuk meningkatkan produktivitasnya, dan mode yang diperbuat oleh perilaku interaktif individu dengan individu lain dalam group, yang biasanya dibangun oleh aturan yang bersifat resiprositas. Perilaku 
interaktif tersebut didesain juga untuk memenuhi akhir tujuan dan beberapanya menjadi instrumental (Hardestry,1977).

Bagi perempuan, kehilangan wilayah kelola dalam rumah tangga akan memberikan dampak fisik maupun psikologis. Secara fisik, dampak yang dapat dirasakan antara lain bagaimana beban kerja menjadi bertambah, ketidakberdayaan ekonomi, menurunnya tingkat kesehatan, lemahnya akses terhadap pendidikan, kesehatan, dan sosial serta membuka celah untuk kekerasan dalam rumah tangga.

Shiva mengemukakan dalam penelitian menunjukkan bahwa perubahan iklim yang cepat memberikan dampak yang buruh bagi perempuan. Hal ini terjadi karena sistem patriarki tidak memberikan banyak pilihan yang tersedia bagi perempuan untuk mengekspresikan pengalamannya sebagai bagian dari yang setara dalam menghadapi krisis lingkungan (Chandraningrum, 2004).

Hardestry mengemukakan ada dua macam perilaku yang adaptif, yaitu perilaku yang bersifat idiosyncratic (caracara unik individu dalam mengatasi permasalahan lingkungan) dan adaptasi budaya yang bersifat dipolakan, dibagi rata sesama anggota kelompok, dan tradisi. Bagi Hardestry, adaptasi dilihat sebagai suatu proses pengambilan ruang perubahan, dimana perubahan tersebut ada di dalam perilaku kultural yang bersifat teknologikal (technological), organisasional, dan ideological. Sifat-sifat kultural mempunyai koefisiensi seleksi seperti layaknya seleksi alam, sejak tedapat unsur variasi, perbedaan tingkat kematian dan kelahiran, dan sifat kultural yang bekerja melalui sistem biologi. Proses adaptif yang aktual sedapat mungkin merupakan kombinasi dari beberapa mekanisme biologis dan modifikasi budaya tersebut diatas. Sehingga adaptasi dapatlah disebut sebagai sebuah strategi aktif manusia (Hardestry, 238-240).

Suharto (2002) menyatakan bahwa definisidaristrategibertahanhidup(coping strategies) adalah kemampuan seseorang dalam menerapkan seperangkat cara untuk mengatasi berbagai permasalahan yang melingkupi kehidupannya. Dalam konteks keluarga miskin, strategi penanganan masalah ini pada dasarnya merupakan kemampuan segenap anggota keluarga dalam mengelola segenap asset yang dimilikinya. Bisa juga disamakan dengan kapabilitas keluarga miskin dalam menanggapi goncangan dan tekanan (Shock and Stress).

Untuk mengatasi goncangan dan tekanan dalam rumah tangga, perempuan dapat mengandalkan strategi adaptif untuk recovery. Strategi bertahan hidup (coping strategies) dapat dikelompokkan menjadi 3 kategori yaitu sebagai berikut:

a. Strategi aktif, yaitu strategi yang mengoptimalkan segala potensi keluarga untuk (misalnya melakukan aktivitasnya sendiri dan mandiri, menggunakan tenaga kerja dari keluarga misalnya anggota keluarga batih dan keluarga luas, memperpanjang jam kerja, memanfaatkan sumber daya alam di lingkungan sekitar dan sebagainya).

b. Strategi pasif, yaitu mengurangi pengeluaran keluarga (misalnya pengeluaran sandang, pangan, pendidikan, rekreasi dan kebutuhan tersier lainnya).

c. Strategi jaringan, misalnya menjalin relasi, baik formal maupun informal dengan lingkungan sosialnya, dan 
lingkungan kelembagaan (misalnya: meminjam uang tetangga, meminjam diwarung, arisan, memanfaatkan program kemiskinan, meminjamuang ke rentenir atau bank, memanfaatkan dana bantuan dan sebagainya).

\section{HASIL DAN PEMBAHASAN}

\section{Deskripsi Lokasi Penelitian}

Desa Nisa merupakan salah satu desa yang terdapat di Pulau Sumbawa, tepatnya di Kabupaten Bima, Kecamatan Woha. Desa Nisa adalah salah satu dari 15 desa yang ada di wilayah Kecamatan Woha, yang merupakan pecahan dari Desa Tente pada bulan Januari tahun 1999. Desa ini diusulkan dalam pemekaran Desa sekaligus dengan pengangkatan Kepala Desa, Sekretaris dan Perangkat Desa pada tanggal 28 Agustus tahun 1999. Desa pemekaran yaitu Desa Persiapan Nisa diresmikan dan sekaligus Pelantikan Kepala Desa dan perangkat dipusatkan di Desa Persiapan Bala, sejak itulah Desa Persiapan Nisa mulai melaksanakan pemerintahan sendiri. Nisa mempersiapkan lokasi dan sarana Kantor Desa, membentuk lembaga lembaga desa untuk menjadi syarat dari Desa Persiapan menjadi Desa Definitif. Maka tahun 2002 Desa Persiapan Nisa diresmikan menjadi Desa Definitif, pada saat berjumlah 8 Desa diantaranya Desa Naru dan Sanolo (Profil Desa Nisa, 2016).

Istilah Nisa pada umumnya orang Bima menyebutkan adalah gunung atau daratan yang ada di tengah laut, nama Nisa oleh orang tua dulu diambil dari kondisi wilayah Nisa yang terletak dan dilingkari oleh anak sungai, sebelah barat berbatasan dengan Induk Sungai sebelah selatan, timur dan utara dilingkari oleh anak sungai sehingga orang tua dulu menyebutkan Kampo Nisa, tapi anak sungai yang melingkari Desa Nisa semakin mendangkal dan sekarang sudah hilang sama sekali dan sudah menjadi wilayah pemukiman penduduk desa, penduduk asli Desa Nisa adalah penduduk yang tinggal di Kampung Nisa, kemudian pendatang yang datang dari Desa Ntonggu Kec. Belo dan sekarang mayoritas menempati Dusun Beringin yang merupakan bagian besar dari penduduk Desa Nisa.

Desa Nisa terletak pada dataran rendah dengan jarak dari Ibukota Kecamatan 0,5 km dan Ibukota Kabupaten $25 \mathrm{~km}$. Desa Nisa memiliki kondisi dataran yang rendah serta berbatasan langsung dengan kali Pela Parado disebelah barat dan juga menjadi sasaran luapan banjir kali Desa Cenggu, disebelah timur. Hampiran setiap tahun, Desa Nisa menjadi sasaran luapan banjir dua aliran sungai tersebut.

Keadaan ekonomi masyarakat Desa Nisa ada yang kategori kaya $0,1 \%$ dan yang miskin 99,99\% dengan mayoritas mata pencaharian penduduk sebagian besar adalah petani. penduduk Desa Nisa juga banyak yang bekerja disektor perdagangan, terutama perempuan, guna meningkatkan kesejahteraan rumah tangga. Berdasarkan penelitian, penduduk Desa Nisa banyak bekerja sebagai pedagang, hal ini dikarenakan letak Desa Nisa yang berada pada jantung kota kecamatan. Selain itu profesi buruh juga menjadi mata pencarian utama. Adapun buruh yang digeluti adalah buruh di pasar (kuli angkut) dan buruh bawang.

Sebagian penduduk Desa Nisa adalah Suku Mbojo dengan mayoritas memeluk agama Islam. Penduduk dari suku pendatang kebanyakan dari suku Jawa, Bugis, dan Sasak. Kondisi 
kemasyarakatan Desa Nisa termasuk dalam masyarakat paguyuban walaupun lokasi desa ini berada dalam jalur utama provinsi. Masyarakat masih memegang teguh nilai toleransi dan kekerabatan/ kekeluargaan yang tercermin dalam aktivitas kesehariannya.

Letak strategis Desa Nisa yang berada dalam jantung kota kecamatan, memberikan peluang usaha bagi para penduduknya, terutama perempuan. Banyak perempuan bekerja membantu menyokong perekonomian rumah tangga. Walaupun sisitem kekerabatan masyarakat Desa Nisa masih patrilial dengan anggapan laki-laki menjadi tulang punggung utama keluarga, hal ini tidak menyurutkan para perempuan untuk bekerja. Kesadaran untuk meningkatkan ekonomi menjadi dasar bagi para perempuan untuk bekerja tanpa melupakan tugas utama sebagai pengelola rumah tangga.

\section{Perempuan Sebagai Penopang Ekonomi Keluarga}

Menurunnya tingkat pendapatan keluarga, seringkali mendesak perempuan untuk mencari alternatif peluang usaha baru. Perempuan berusaha memutar otak bagaimana agar ketahanan pangan bisa tercapai, anggota keluarga tercukupi kebutuhannya, bahkan terkadang perempuan rela mengabaikan kepentingan pribadinya agar roda ekonomi keluarga tetap berjalan. Perempuan merupakan pihak yang paling sensitif terhadap perubahan ekonomi dalam rumah tangga.

Peran luar biasa yang banyak diemban oleh perempuan tidak lain adalah sebagai tulang punggung keluarga. Perempuan tidak hanya berkutat pada ranah domestik saja, melainkan juga sebgai pencari nafkah utama. Dalam kesehariannya perempuan melakukan beban ganda, sebagai pencari nafkah dan menguurus pekerjaan domestik. Seperti halnya yang terjadi pada perempuan di wilayah Nusa Tenggara Barat, banyak dijumpai perempuan yang bekerja di sektor informal. Bahkan menjadi buruh kasar yang didominasi oleh kaum lelaki. Minimnya akses lapangan kerja dan rendahnya pendidikan menjadikan perempuan menggapai pekerjaan yang jauh dari sifat kodratinya yang halus, lembut, pengayom, dan sebagainya. Menjadi buruh pengangkut batu bata, kuli bangunan, tukang angkut sampah, buruh tani, merupakan pekerjaan yang didominasi kaum lelaki, namun di wilayah NTB sudah menjadi hal yang umum jika perempuan berkecimpung di bidang ini.

Tidakmenjadihalyangmengherankan jika pemandangan yang menyuguhkan ketangguhan wanita banyak terjadi di NTB. Perempuan-perempuan tangguh dapat dijumpai di pasar-pasar, bertengger di atap truk, proyek bangunan, tambang batu dan sebagainya. Pemandangan ini menjadi secercah motivasi bagi perempuan lain dalam memberdayakan daya dan kemampuan perempuan untuk berpartisipasi dalam ekonomi rumah tangga.

\section{Strategi Adaptif Para Perempuan dalam Mempertahankan Ekonomi Rumah Tangga Pasca Bencana Banjir}

\section{a. Perubahan Kehidupan Pasca Banjir}

Bencana banjir yang terjadi di kabupaten Bima awal tahun 2017 lalu memberi perubahan pada kehidupan masyarakat, salah satunya yaitu kehidupan masyarakat Desa Nisa sebagai salah satu desa terdampak akibat bencana banjir tersebut. Salah satu perubahan yang terjadi di Desa Nisa pasca banjir yaitu perubahan 
kondisi ekonomi masyarakat, terutama terhadap perempuan-perempuan yang bekerja sebagai penopang rumah tangga.

Sebagian besar masyarakat Desa Nisa banyak berprofesi sebagai buruh bawang baik laki-laki maupun perempuan. Daerah ini merupakan penghasil bawang merah di NTB. Sebelum terjadi banjir pendapatan rumah tangga hanya bergantung dari penghasilan suami yang rata-rata bekerja sebagai buruh bawang. Sebelum terjadi banjir kondisi ekonomi masyarakat masih bergantung dari penghasilan suami yang rata-rata bekerja sebagai buruh bawang, namun setelah terjadi banjir penghasilan sebagai buruh bawang menurun akibat dari banjir yang banyak merendam sawah warga sehingga banyak tanaman bawang yang rusak akibat banjir tersebut. Sehingga membuat perempuan sebagai ibu rumah tangga mencari inisiatif lain dengan berjualan kue sehingga hasil dari berjualan kue tersebut bisa dijadikan sebagai penghasilan tambahan di dalam kehidupan rumah tangga.

Pada umumnya perempuan bekerja bukanlah semata-mata untuk mengisi waktu luang atau mengembangkan karir, melainkan dilakukan untuk mencari nafkah untuk memenuhi kebutuhan rumah tangga, karena pendapatan yang diperoleh suaminya dikatakan kurang mencukupi sehingga banyak perempuan di Desa Nisa yang bekerja.

Kehidupan yang ada di Desa Nisa tersebut tidak terlepas dari interkasi sosial yang terjalin diantara mereka. Dalam menjalani kehidupan sebagai makhluk sosial sudah tentu kita akan membutuhkan bantuan dari orang lain di sekitar kita. Seperti halnya interaksi dan komunikasi yang ada di Desa Nisa ini. Kondisi interaksi tersebut terlihat dari kehidupan sosial masyarakat Desa Nisa dengan saling bergotong royong bersih desa setiap bulan guna untuk mengantisipasi bencana banjir. Selain itu masyarakat Desa Nisa juga membentuk persatuan ibu-ibu PKK. Kegiatan ini selain membahas masalah sosial juga masalah pendidikan, lingkungan juga di dalamnya diadakan arisan. Kegiatan ini juga sebagai wadah untuk saling mengakrabkan para warga masyarakat.

\section{b. Eksplorasi Ekonomi Keluarga Pasca Bencana Banjir Bandang}

Keikutsertaan perempuan dalam usaha meningkatkan kesejahteraan keluarga adalah merupakan perwujudan dari perannya secara dinamis dari kedudukan dan status perempuan dalam suatu sistem sosial tempat perempuan tersebut berada.

Peran perempuan sangat membantu sebagai penunjang perekonomian rumah tangga, ini tampak jelas di Desa Nisa banyak perempuan yang bekerja guna untuk membantu perekonomian rumah tangga. Peran perempuan bukan hanya bekerja yang berkaitan dengan kedudukan dan kewajiban sebagai ibu rumah tangga saja, seperti: melayani suami, memasak, membersihkan rumah, mengasuh anak dan lain sebagainya. Tetapi juga membantu bagaimana caranya memenuhi kebutuhan keluarga. Hal ini terlihat dari banyaknya perempuan yang bekerja sebagai pedagang, petani, bahkan sebagai buruh bawang.

Keadaan perempuan di Desa Nisa yang berperan ganda, yaitu disamping melakukan pekerjaan rumah tangga, namun juga melakukan pekerjaan di luar rumah tangganya untuk mendapatkan nafkah. Untuk memenuhi kebutuhan keluarganya, para perempuan tidak hanya 
melakukan satu pekerjaan saja namun juga ada pekerjaan-pekerjaan lain yang juga mereka lakukan, misalnya sebagai buruh tani ketika musim tanam padi tiba. Penghasilan dari buruh tani tersebut mereka biasanya dibayar 50.000 perhari dengan waktu kerja 9 jam.

Selain itu beban tanggungan keluarga yang tidak hanya cukup dari mengandalkan penghasilan suami, misalnya untuk biaya pendidikan anak, biaya belanja sehari-hari, biaya listrik dan lain sebagainya, sehingga membuat perempuan ikut aktif dalam bekerja membantu perekonomian keluarga.

Bencana banjir bandang di Kabupaten Bima juga menimbulkan kerugian yang cukup besar bagi warga desa Nisa. Banjir tersebut tidak hanya merugikan masyarakat secara material namun juga secara psikis karena banjir tersebut menimbulkan traumatik bagi masyarakat. Akibat dari bencana banjir bandang tersebut kerugian yang dialami oleh warga desa Nisa cukup besar, tidak hanya atap rumah mereka yang rusak parah, namun juga peralatan elektronik seperti TV, kulkas juga ikut rusak akibat terendam banjir. Selain itu ternak-ternak mereka juga mati akibat banjir tersebut.

\section{c. Perbedaan Pekerjaan Sebelum dan Sesudah}

Desa Nisa merupakan desa yang memiliki letak strategis, yaitu dekat dengan pasar dan letaknya di dekat jalur jalan raya provinsi. Namun, letak kota yang berada di lembah juga menjadi ancaman genangan air. Apalagi ditambah lokasi dua sungai yang membelah desa Nisa tidak kuat menampung debit air yang turun dari bendungan Parado. Banjir yang berulang telah mengubah kondisi sosial, budaya, dan ekonomi masyarakat Desa Nisa yang berimbas pada perbedaan pekerjaan sebelum dan sesudah bencana banjir bandang.

Kaum perempuan beradaptasi dengan perubahan bencana banjir dengan mengubah pola ketergantungan terhadap pendapatan suami. Bila sebelumnya pendapatan keluarga hanya mengandalkan sepenuhnya kepada suami maka pasca banjir, banyak kaum perempuan desa Nisa yang mencoba mencari peruntungan pekerjaan untuk menunjang ekonomi keluarga. Alternatif-alternatif pekerjaan baru dijadikan sampingan selain pekerjaan utama. Bahkan menjadi pilihan bagi perempuan yang tidak bekerja atau tidak berpenghasilan. Akan tetapi ada juga yang tidak mengalami perubahan pekerjaan pasca bencana banjir bandang. Perempuan memilih menggeluti usaha yang sama dengan skala yang sama juga terkait dengan faktor kemampuan ekonomi mereka.

\section{d. Pekerjaan yang Dilakukan setelah Bencana Banjir}

Bencana banjir yang menerjang Desa Nisa telahmengubah pola pikir masyarakat, khususnya perempuan tentang strategi bertahan hidup. Perubahan strategi bertahan hidup ini sebagai alternatif dalam mempertahankan tiang ekonomi rumah tangga karena masyarakat sadar bencana banjir ini berulang setiap tahunnya.

Tidak semua kaum perempuan di Desa Nisa mencari pekerjaan pasca bencana banjir. Banyak juga perempuan yang tetap mengandalkan pendapatan dari suami dan hasil pertanian. Keterbatan menjadi alasan utama bagi perempuan untuk meraih peluang-peluang usaha ditambah dengan perubahan-perubahan kondisi perekonomian keluarga.

Uniknya, sebagai sebagai ibu rumah tangga, perempuan tidak mengakui jika 
ibu rumah tangga adalah sebuah profesi. Pengetahuan mereka jika perempuan yang bekerja menghasilkan uang baru dianggap bekerja, walaupun perempuan Desa Nisa ini memiliki pekerjaan sampingan. Konstruksi sosial tentang definisi kerja melatarbelakangi penilaian sosial tentang pekerjaan tersebut. Komersialisasi serta orientasi penghargaan terhadap status sosial ekonomi menempatkan perempuan dalam kerja yang tidak tampak (invisible).

Konstruksi sosial ini menjadi titik lemah bagi perempuan dalam eksistensi di rumah tangga. Mereka tidak menyadari bahwa eksistensi dalam rumah tangga ditunjukkan dengan peran yang dijalani, walau sebagai ibu rumah tangga. Contoh kasus seperti berikut, pertanyaan yang sering dilontarkan adalah "apa pekerjaan Anda", sebagian besar menjawab tidak bekerja, hanya ibu rumah tangga.

\section{e. Strategi Adaptif Perempuan Desa Nisa Pasca Banjir Bandang}

Seperti kita ketahui dalam uraian teoritis di atas, perempuan sangat sensitif terhadap perubahan sekecil apapun dalam keluarga. Berbagai usaha dilakukan sebagai bagian dari strategi adaptif pascabanjir. Strategi adaptif tidak hanya menyangkut pada pencarian profesi baru atau memanfaatkan sumber daya alam yang tersedia. Namun, strategi adaptif yang dilakukan oleh perempuan di Desa Nisa juga menyangkut strategi aktif, pasif, dan strategi jaringan.

Strategi bertahan hidup (coping strategies) dalam mengatasi goncangan dan tekananekonomi dapat dilakukan dengan berbagai cara. Strategi bertahan hidup dapat dikelompokkan menjadi 3 kategori yaitu strategi aktif, pasif dan jaringan. Adapun strategi-strategi adaptif yang dilakukan oleh perempuan Desa
Nisa adalah sebagai berikut:

1) Strategi aktif, misalnya mengoptimalkan segala potensi keluarga.

Optimalisasi anggota keluarga diharapkan dapat menambah pendapatan keluarga. Contohnya dengan memberdayakan orang terdekat seperti anak, keponakan, dan orang tua. Hal lain yang dilakukan adalah memperpanjang jam kerja serta menambah peluangpeluang usaha lain sesuai dengan kapasitasnya misalnya berjualan kue, berdagang, menjadi buruh, danbertani. Selain itu memanfaatkan sumber daya alam dilingkungan sekitar juga dilakukan sebagai bagian strategi adaptif, walau sumber daya alam terbatas akibat terjangan banjir.

\section{2) Strategi pasif, yaitu mengurangi pengeluaran keluarga.}

Tindakan pengurangan kebutuhan keluarga dilakukan oleh hampir seluruh informan yang menjadi fokus penelitian. Hal yang dilakukan dalam strategi pasif adalah mengurangi pengeluaran untuk kebutuhan tersier. Sebagian besar perempuan di Desa Nisa mengemukakan mengurangi pengeluaran untuk rekreasi, biaya komunikasi, jajan, pembelian sandang, aksesori rumah.

\section{3) Strategi jaringan, misalnya menjalin relasi, baik formal maupun informal dengan lingkungan sosialnya, dan lingkungan kelembagaan.}

Strategi jaringan yang dilakukan oleh perempuan Desa Nisa adalah meminjam uang tetangga, namun tindakan ini terbatas sekali karena ada prinsip-prinsip budaya yang menjadi konstruksi sosial dalam kehidupan masyarakat Bima, yaitu budaya malu. Mereka mencoba sebisa mungkin 
untuk mengutang kepada pihak terdekat. Strategi lain yang dilakukan antara lain mengutang diwarung namun tidak dalam skala yang besar. Berdasarkan penuturan perempuan di desa Nisa, mereka tidak pernah memanfaatkan program kemiskinan bahkan tidak mempunyai informasi terhadap program kemikinan.

Memberdayakan anggota keluarga menjadi salah satu strategi adaptif yang dilakukan para perempuan di desa Nisa pasca banjir bandang. Biasanya memerdayakan anggota keluarga dimulai dari anggota terdekat dahulu yaitu anak, ketika anak susah siap bekerja maka diberikan keleluasaan untuk bekerja. Selain memberdayakan keluarga, strategi adaptif yang bersifat aktif antara lain yaitu memperpanjang jam kerja dan memanfaatkan sumber daya alam.

\section{f. Aspek Ketersediaan Sumber Daya Lokal untuk Menunjang Strategi Adaptif}

Sebagian besar penduduk Desa Nisa mengandalkan pertanian sebagai mata pencarian utama dengan memanfaatkan sumberdayaalamyangada.Hasilpertanian digunakan untuk mencukupi kebutuhan sehari-hari selebihnya dijual. Selain padi, tanaman lain yang dikembangkan adalah jagung dan kacang-kacangan. Jumlah area yang terjangkau irigasi meningkat sebesar 10 Ha per tahunnya. Jumlah fasilitas pertanian bertambah 1 unit per tahunnya. Serta tingkat pendapatan Masyarakat yang semakin meningkat walaupun tidak seimbang dengan nilai jual hasil petani dibandingkan dengan nilai pembelian bibit.

Hasil penelitian mengindikasikan ketergantungan masyarakat Desa Nisa yang tinggi terhadap alam. Pengolahan sumber daya alam menggunakan sistem irigasi telah lama diterapkan oleh masyarakat, apalagi ditambah adanya bendungan Parado yang mengaliri lahan pertanian. Pasca banjir, sumber daya alam tidak bisa memberikan harapan untuk bertahan hidup akibat dampak kerusakan yang ditimbulkan.

Kondisi yang berubah pasca banjir baik fisik maupun non-fisik (sosial, ekonomi, dan budaya) menuntut terjadinya pergeseran peran kaum perempuan. Kaum perempuan dituntut untuk menyesuaikan diri terhadap kemungkinan kondisi yang beruba untuk mempertahankan kelangsungan hidup anggota keluarganya. Mereka mengabaikan nilai dan norma yang dipegang teguh, salah satunya adalah dengan meminta bantuan kepada orang tua, padahal biasanya mereka yang memberikan sedikit dari hasil panen.

\section{g. Peluang-Peluang Usaha yang Dikembangkan}

Kondisi pascabanjir banyak memberikan peluang usaha untuk dikembangkan, walau tidak dapat sepenuhnya bergantung kepada alam. Bagi perempuan, kehilangan wilayah kelola rumah tangga baik itu peralatan maupun aktivitas, akan memberikan pukulan yang menyakitkan. Disamping akan menambah beban kerja juga berdampak pada kesehatan dan potensi kekerasan dalam rumah tangga.

Sebagai pengelola rumah tangga, seringkali perempuan lebih sensitif dibandingkan laki-laki. Apalagi jika perempuan tersebut adalah tulang punggung keluarga, berbagai strategi diterapkan untuk kesiapan dan ketahanan pangan. Peran perempuanyang vitaldalam 
keluarga seringkali mendesak perempuan untuk mencari alternatif-alternatif pendapatan tambahan, seperti yang terlihat pada kasus ibu Yn. Perempuan di Desa Nisa banyak terdesak untuk mencari peluang usaha lain untuk dikembangkan, mulai dari menanan tanaman pangan di halaman, menjadi buruh kupas bawang, buruh cuci, pedagang keliling, dan memproduksi makanan. Dengan demikian terlihat bahwa ada peningkatan beban kerja karena desakan ekonomi akibat hilangnya wilayah kelola atau menyempitnya wilayah usaha.

\section{h. Dasar Motivasi Melakukan Strategi Adaptif}

Setahun pasca banjir, kondisi perekonomian masyarakat Desa Nisa tidak bisa sepenuhnya stabil. Walaupun roda perekonomian terus berputar, masyarakat mengaku masih kesulitan untuk dapat kembali kepada keadaan ekonomi seperti sebelum banjir. Masih banyak kerugian-kerugian yang belum bisa ditutup dari pendapatan dan strategi adaptif yang dilakukan.

Berdasarkan hasil wawancara dengan para informan, dasar para perempuan melakukan strategi adaptif sebagian besar karena faktor recovery ekonomi rumah tangga. Mereka berharap dengan melakukan strategi adaptif dapat menopang ekonomi rumah tangga, menutup kerugian pasca banjir, menambah modal untuk usaha lain, dan menabung untuk mengantisipasi kemungkinan banjir berulang.

\section{i. Kendala dalam Melakukan Strategi Adaptif}

Ketika perempuan memiliki peran ganda dalam menjalankan tugasnya, kadang kala ada masalah-masalah yang harusdihadapi perempuan. Selainberperan dalam hal menjaga anak, peran anggota keluarga yang tidak bisa membantu secara langsung adalah mendukung kegiatan usaha, karena anggota keluarga yang lain memiliki pekerjaan yang berbeda. Peran anggota keluarga disni adalah mengurus nafkah demi mencukupi kebutuhan hidup sehari-hari.

Kendala yang dihadapi dalam melakukan strategi adaptif antara lain terbatasnya modal serta sumber daya manusia dari perempuan Desa Nisa itu sendiri. Rata-rata pendidikan tertinggi adalah SMA selain itu ketrampilan usaha yang dimiliki juga terbatas, jadi mereka hanya mengandalkan dari sektor perdagangan, jasa, dan pertanian.

Selain kendala di atas, terdapat faktor luar yang memengaruhi usaha strategi adaptif perempuan yaitu sarana prasarana yang tidak memadai serta tingkat pendapatan yang kurang karena dipengaruhi cuaca. Hal ini signifikan dengan profesi yang banyak ditekuni oleh perempuan Desa Nisa yaitu sebagai buruh pengupas bawang. Perubahan cuaca yang tidak menentu memberikan impak bagi hasil pertanian hingga memberikan efek domino kepada perempuan Desa Nisa.

Faktor lain yang berperan penting dalam strategi adaptif perempuan adalah penguatan kelembagaan yang dikung oleh sistem pemerintahan desa. Namun, hal ini menjadi kendala yang berat karena belum adanya kelembagaan ekonomi mikro desa yang kuat, yang mampu memberikan pelayanan kredit modal usaha untuk membangkitkan perekonomian bagi warga desa berupa program simpan pinjam, yang sasarannya masyarakat umum maupun khusus perempuan. 
KESIMPULAN DAN SARAN

Strategi adaptif perempuan di Desa Nisa pasca banjir bandang dilakukan dengan menggunakan berbagai strategi antara lain strategi aktif, pasif, dan memanfaatkan jaringan. Strategi aktif yang dilakukan oleh perempuan Desa Nisa antara lain dengan menggunakan SDM untuk meningkatkan ekonomi, yaitu SDM dari orang terdekat misalnya anak dan suami. Selain itu adalah memperpanjang jam kerja untuk meningkatkan pendapatan dengan menambah usaha pengelolaan. Tindakan lain yaitu dengan memanfaatkan sumber daya walau terbatas, namun mereka masih berusaha mendapatkan akses ke sumber daya alam.

Strategi pasif yang dilakukan oleh perempuan Desa Nisa antara lain dengan mengurangi pengeluaran keluarga. Hal ini dilakukan dengan koordinasi dari seluruh anggota keluarga. Strategi jaringan dilakukan dengan meminjam uang darikeluargaterdekat, mengutang di warung, dan meminjam di bank. Dengan usaha tersebut dapat meningkatkan perekonomian rumah tangga. Sedikit demi sedikit mereka berusaha menyusun kembali tiang perekonomian rumah tangga akibat banjir.

Kendala-kendala yang dihadapi dalam melakukan strategi adaptif adalah kurangnya keterampilan untuk meningkatkan peluang usaha, sumber daya alam yang terbatas, serta tidak adanya penguatan kelembagaan yang berfokus kepada ekonomi kaum perempuan.

Perempuan Desa Nisa sebaiknya lebih bisa memanfaaatkan sumber daya alam dengan mengolahnya menjadi barang yang lebih bernilai jual. Perempuan harus lebih kreatif dan inovatif, hal ini bisa dengan memanfaatkan teknologi internet untuk menambah wawasan bagi pemerintah sebaiknya memberikan pelatihan-pelatihan keterampilan bagi penduduk Desa Nisa agar tidak bergantung pada sumber daya lokal. Serta memberikan penguatan kelembagaan untuk memberdayakan perempuan misalnya dengan bank khusus perempuan, bank sampah, simpan pinjam khusus perempuan, dan berbagai penguatan lainnya.

\section{DAFTAR PUSTAKA}

Fakih, Mansour. 2012. Analisis Gender dan Transformasi Sosial. Yogyakarta: Pustaka Pelajar.

Goode, William J. 1995. Sosiologi Keluarga. Jakarta: Bumi Aksara.

Hardesty, D. L. (1977). Ecological Anthropology, New York: McGrawHill. Hardesty, D. L. (1977). Ecological Anthropology, New York: McGraw-Hill.

Hunga, Ina dan Dewi Candraningrum. 2017. Ekofenimisme IV (Tanah, Air, dan Rahim Rumah). Salatiga: Parahita Press.

Jurnal Perempuan Untuk Pencerahan dan Kesetaraan. 2013. Karier dan Rumah Tangga. Jakarta: Yayasan Jurnal Perempuan.

Khairuddin. 1992. Sosiologi Keluarga. Yogyakarta: Nur Cahaya.

Loekman Soetrisno. 1995. Menuju Masyarakat Partisipatif. Yogyakarta: Kanisius.

Ritzer, George. 2010. Teori Sosial Modern. Yogyakarta: Kreasi Wacana.

Sajogyo, Pudjiwati. 1989. Sosiologi Pembangunan. Jakarta: IKIP Jakarta.

Soekanto, Soerjono. 2009. Sosiologi Keluarga. Jakarta: Rineka Cipta.

Suwarsono dan Alvin. 2013. Perubahan Sosial dan Pembangunan. Jakarta: LP3ES. 